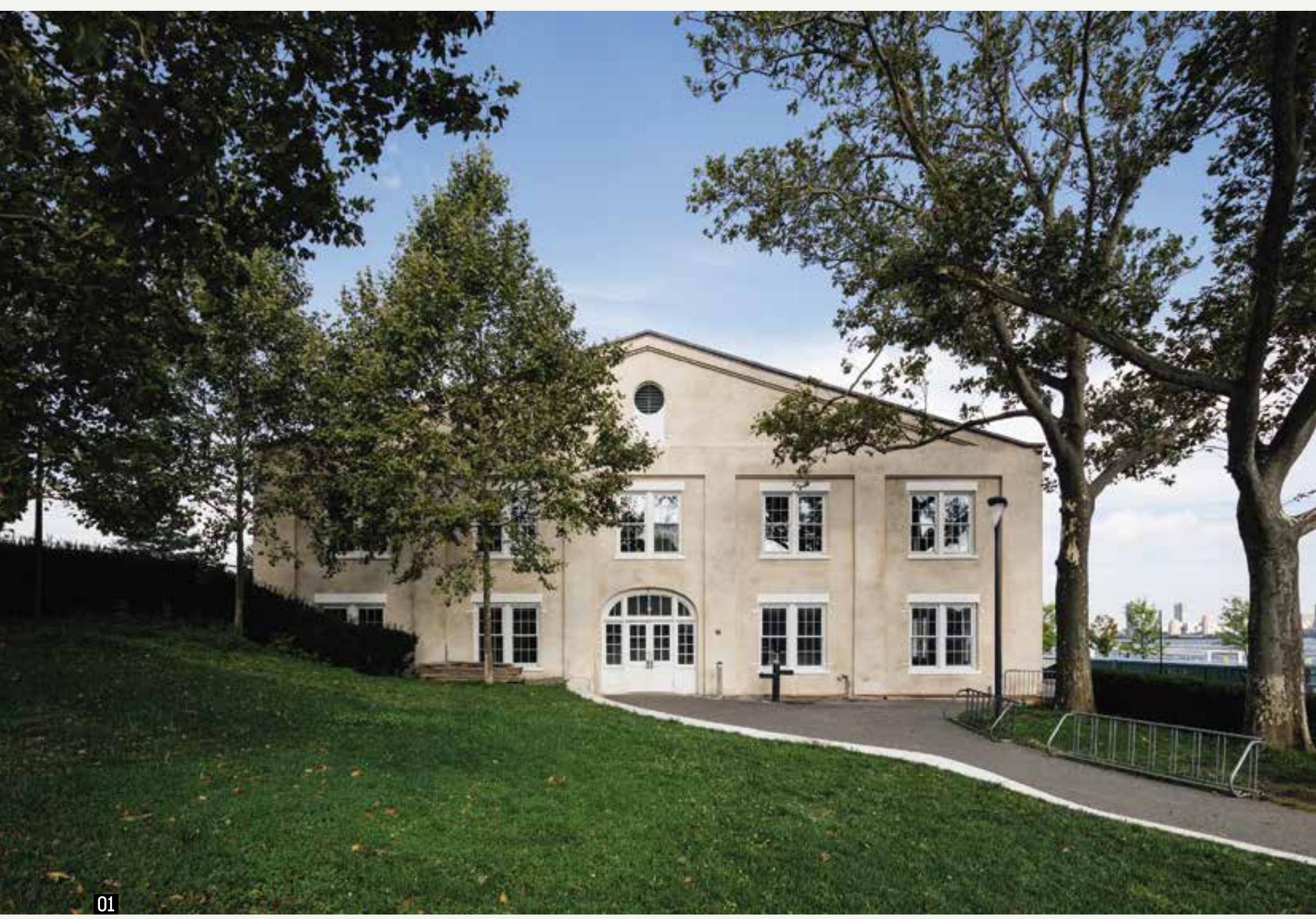

\title{
KATONAI HAGYATÉK
}

LMCC MÜVÉSZETI KÖZPONT, GOVERNORS ISLAND | NEW YORK, USA

_A megújuló New York-i sziget másfél évszázados

raktárépületéből jött létre ez a múvészeti központ, gyönyörú

fedélszékkel, eklektikus programmal. 


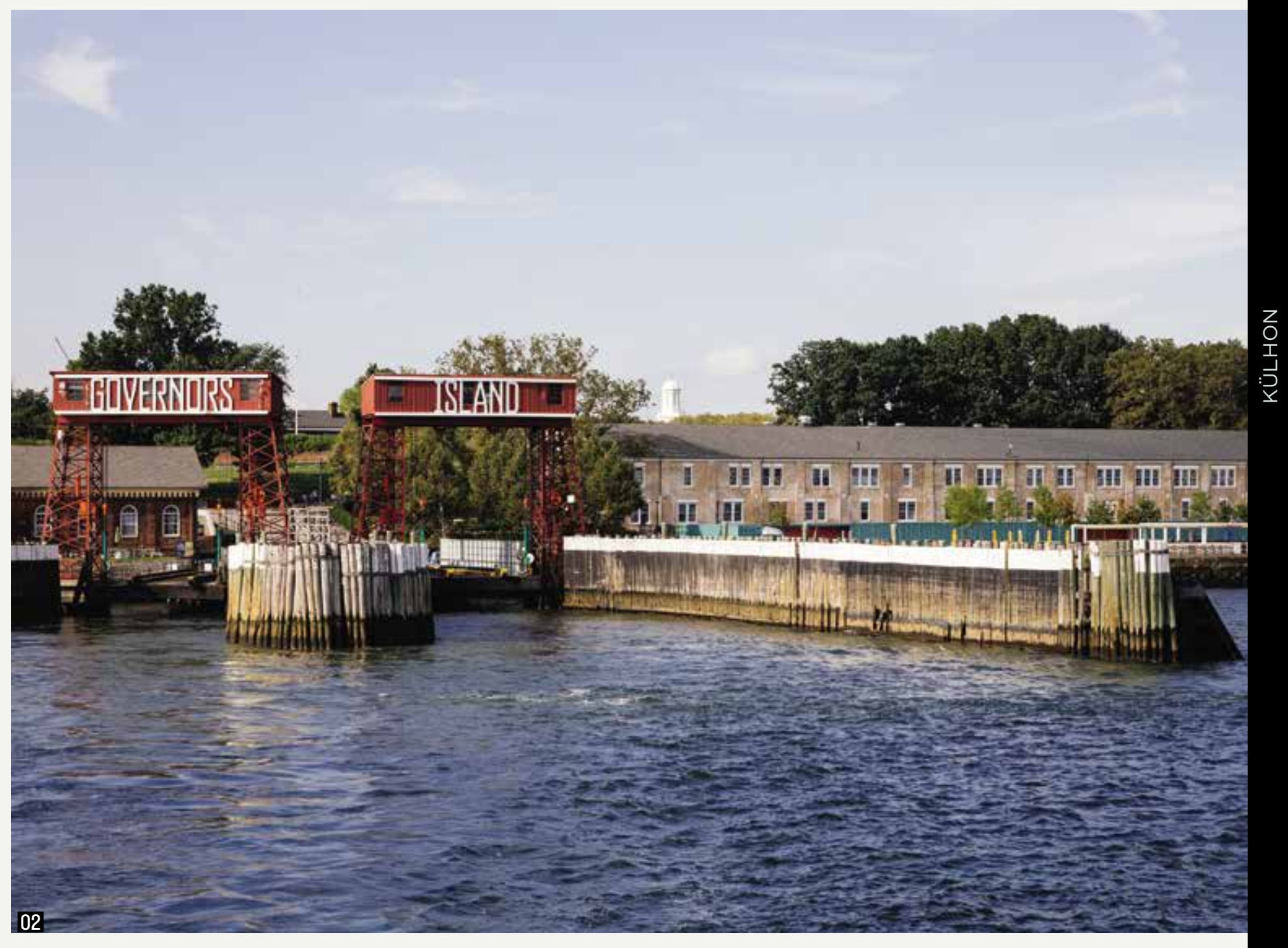

ÉPÍTÉSZ|

Jay L. Berman
SZERZŐ |

Csanády Pál
01

02
A közel százötven éves épület véghomlokzata Az új kulturális központ a Manhattan felől érkező komp megállója mellett található

_ A New Yorkban járt turistákat legtöbbször hiába kérdezgetjük, voltak-e a Governors Islanden, pedig a sziget a város kellős közepén van, Manhattantől délre, a Szabadság-szobortól is csak pár száz méterre. Ismeretlenségének legfőbb oka, hogy a függetlenségi háború óta zárt katonai terület volt egészen I966ig, de ezután is a Parti Örség bázisa volt. Közben, I9II-ben közel háromszorosára bővítették a szigetet, köszönhetően az egyik földalattiból kikerült földmennyiségnek. Végül 2003-ban jelképes egy dollárért adták át a városnak azzal a kikötéssel, hogy csak közösségi, kulturális célra és természetesen parkként használhatják, tilos a lakások vagy kaszinók betelepítése. Korábban ötezer főnyi katonaság is lakott a szigeten, de 20I5-ig még látogatni is csak hétvégenként lehetett. 20I4-ben nyílt meg a park első üteme, 20I6-ban pedig a kilátódombokkal tarkított déli rész, ahonnan remekül fotózható a Szabadság-szobrot. Az urbanisztikai tervet a West 


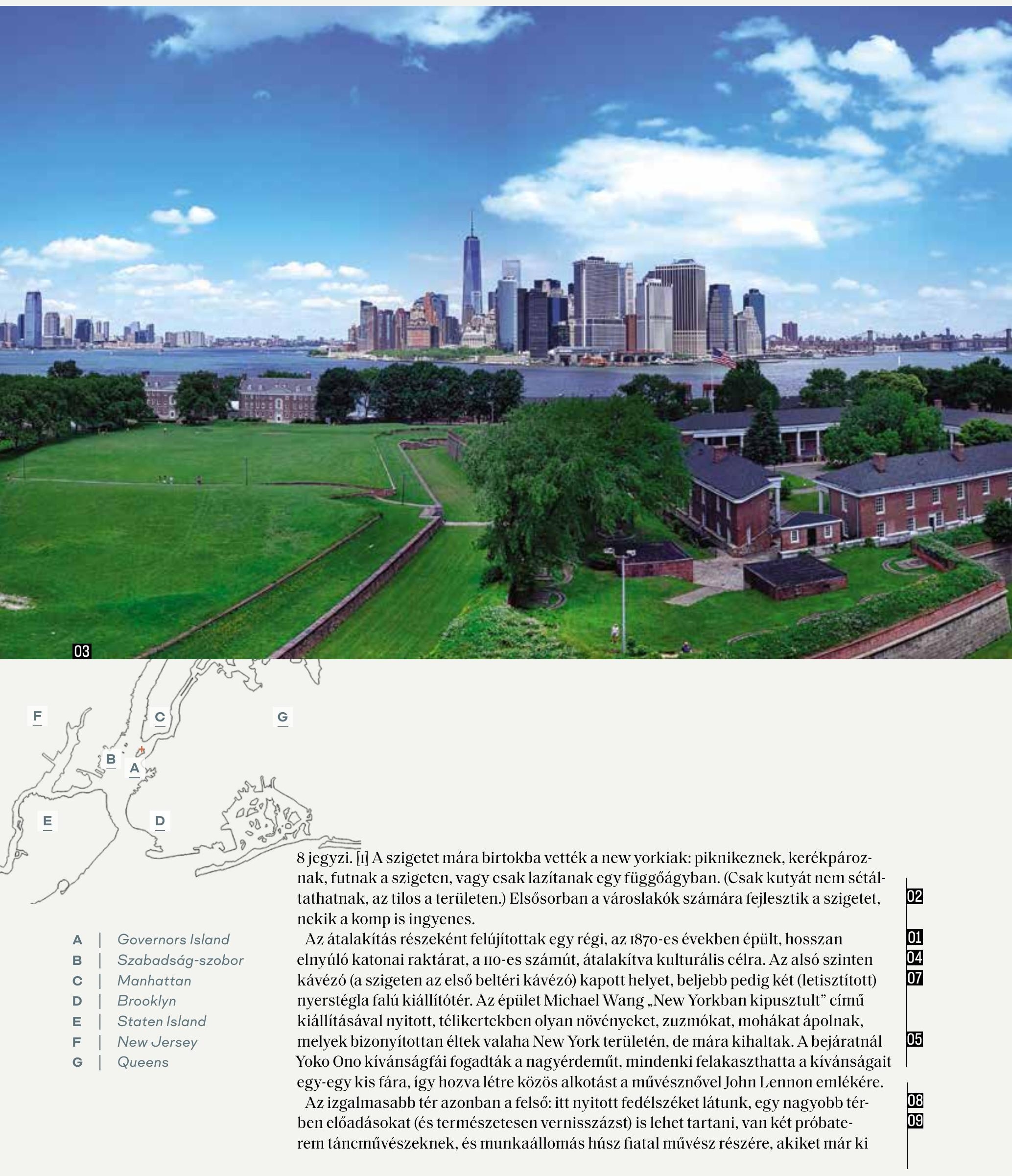




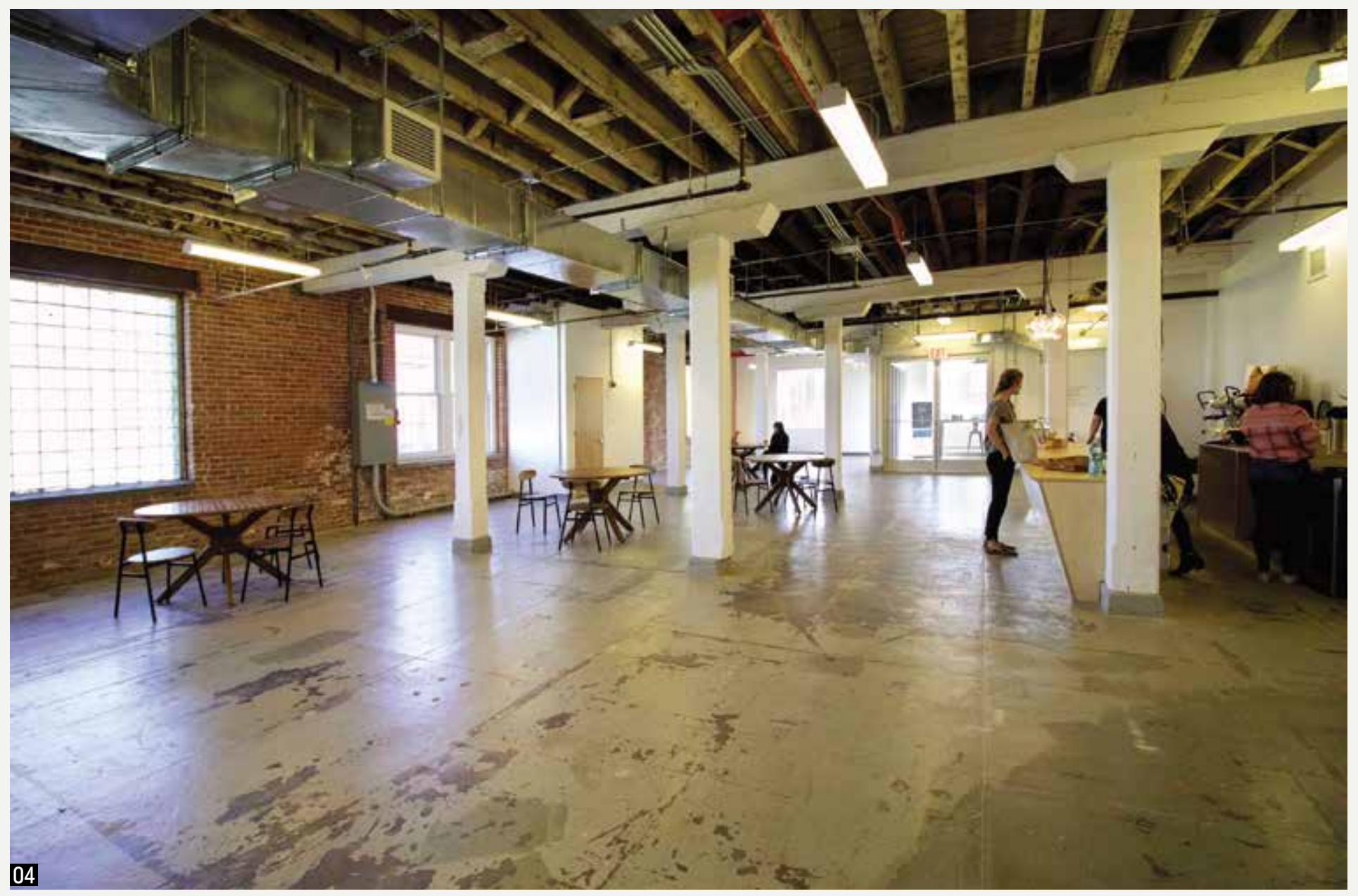

03 A Governors Island egy zöld sziget New York közepén, kilátással a felhőkarcolókra. (Az épület gerince látszik, középen, a fa mögött; fotó: Nestor Rivera Jr., Wikimedia Commons)

04 A földszinti kávézó lofthangulattal

is választottak. A felső szint a hátsó fronton az utcáról is megközelíthető, így a különböző funkciók gond nélkül tudnak működni.

A beruházó, a Lower Manhattan Cultural Council (LMCC) közel ötvenéves civilszervezet, és ez az első állandó székhelye. Annyit érdemes tudni a szervezetről, hogy David Rockefeller és Flory Barnett eredetileg azért hozták létre, hogy a WTC Plaza kopár terét humanizálják... Később lett fiatal müvészek támogatója (ösztöndíjakkal, lakhatással és fellépési lehetőséggel), és a WTC tornyok elleni terrortámadás óta „hajléktalan”. A Governors Island-i épületet már 20I0-ben megkapták, még a szervezet alapítójának, Flory Barnettnek az életében, aki az épület átalakítását és tavalyi újranyitását már nem érte meg. Ő egyébként valódi filantróp volt, nemcsak pénzt gyüjtött, de gyakran meg is vendégelte pártfogoltjait, unokái, dédunokája mellett erre is jutott energiája. [2] Most, a 2020-as szezonban a járvány okozta kényszerű leállás idején rászoruló művészeknek nyújt átmeneti lakhatást ez az épület. Flory Barnett örülne, ha látná.

Az átalakitás

részeként

\section{6}

felújítottak egy

régi, az I870-es

években épült,

hosszan elnyúló

katonai vaktárat,

átalakitva

kulturális célva 


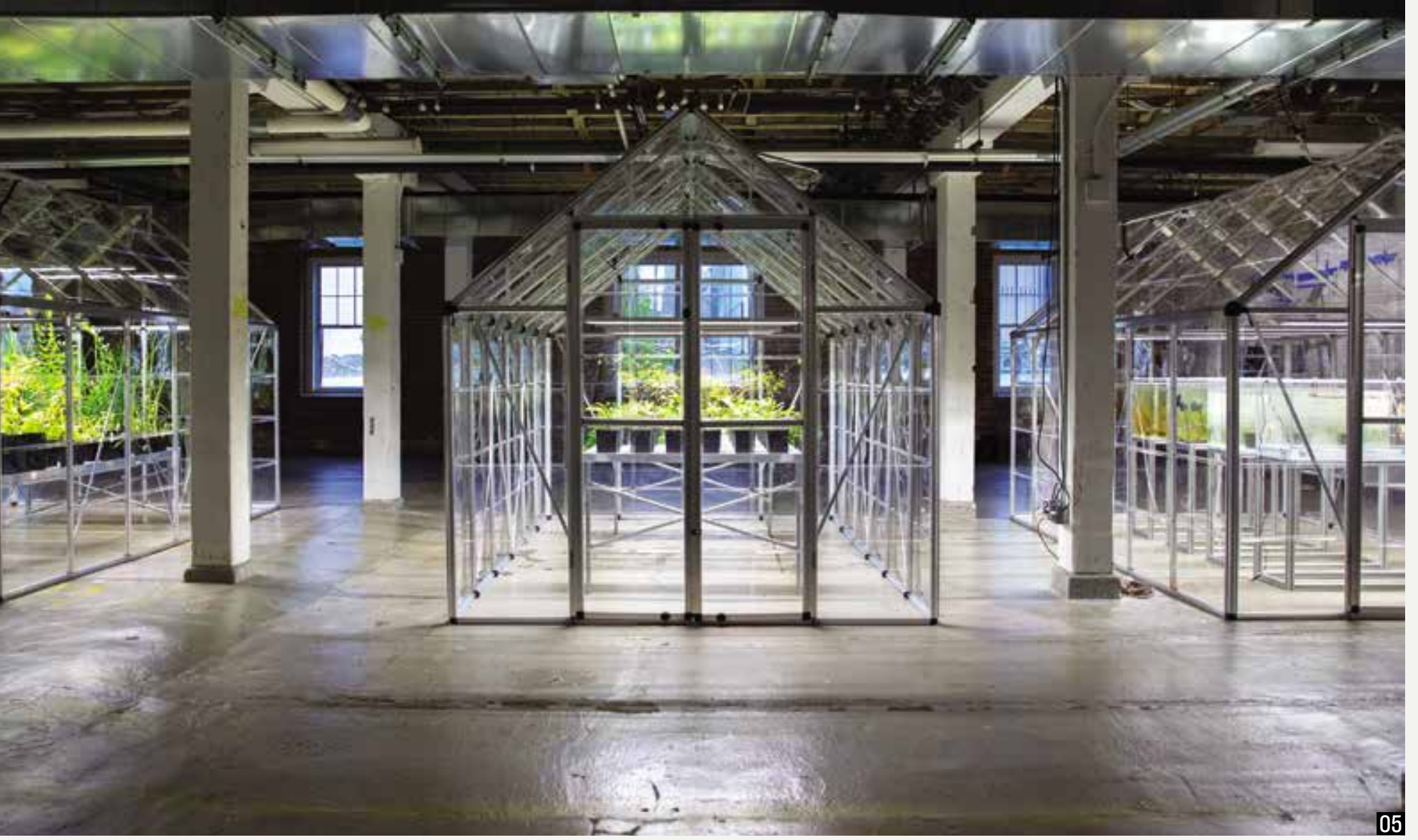

05 Michael Wang „New Yorkban kipusztult” című kiállításának télikert-installációi

06 Felső szint alaprajza

$07 \quad$ Alsó szint alaprajza

08-09 A felső kiállítótér a nyitott fedélszékkel
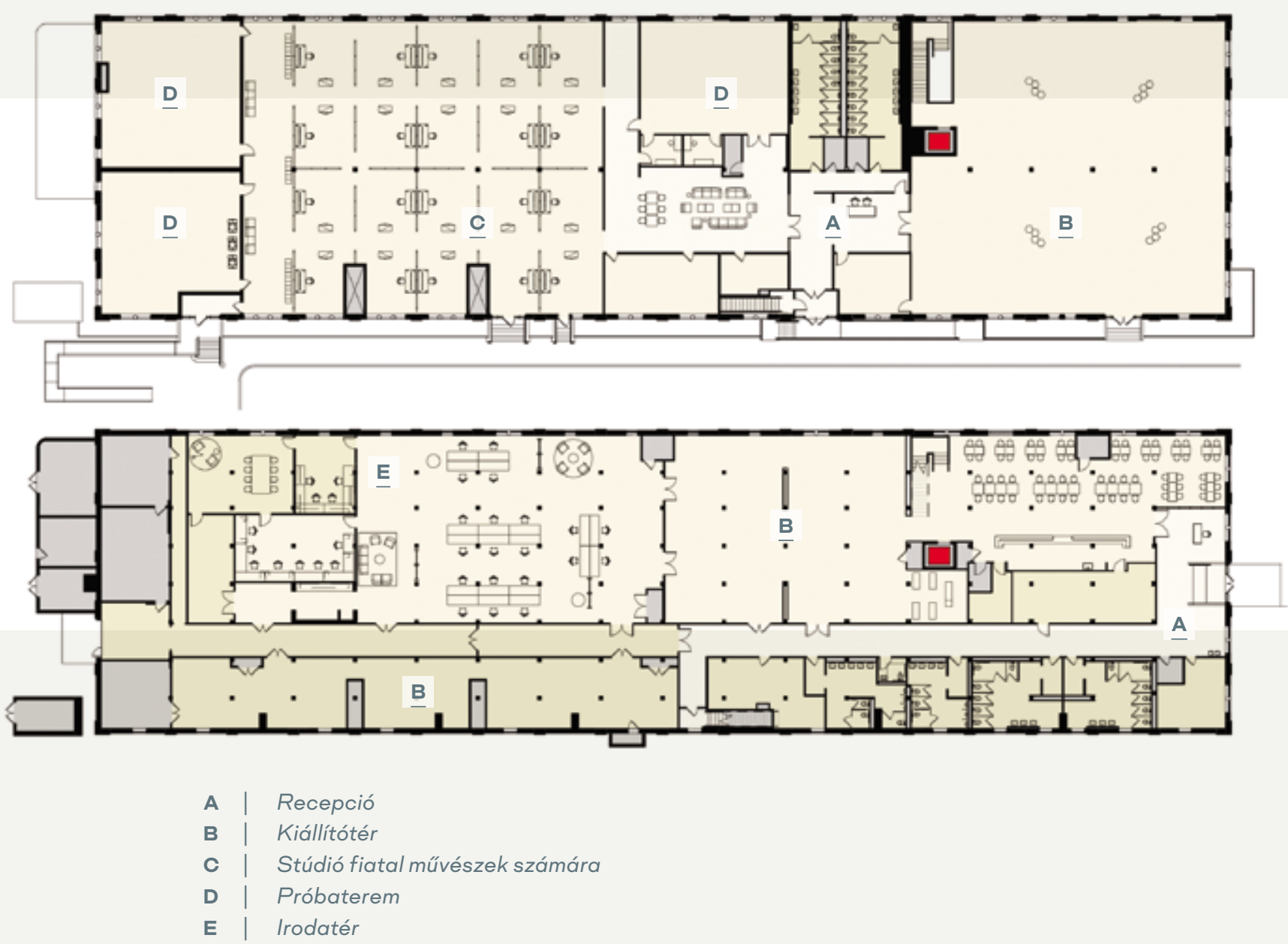

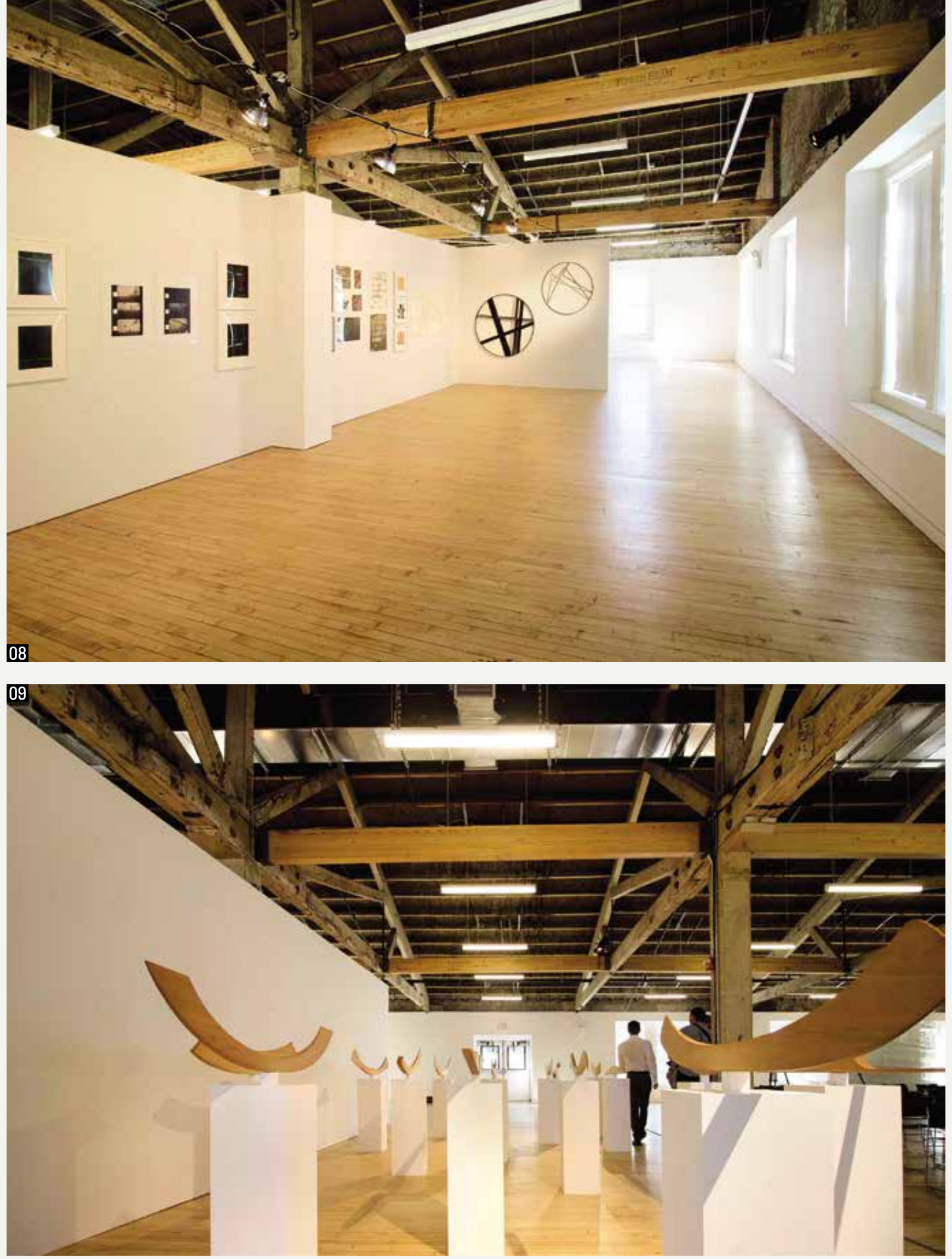

ÉPÍTÉSZ: Jay L. Berman | MEGBÍZÓ: Lower Manhattan Cultural Council | TERVEZŐK: Pei Cobb Freed \& Partners; Adamson Associates Architects | STATIKA ÉS GÉPÉSZET: Buro Happold Consulting Engineers PC, New York I FOTÓ: Nicole Saraniero (Untapped Cities), David Gonsier, Zachary Tyler Newton / v2com, Nestor Rivera / Wikimedia commons
IRODALOM / REFERENCES

[1] Davis, Brian - Geuze, Adriaan: „The New Public Landscapes of Governors Island", Places Journal, 2011/02/07, DOI: $<10.22269 / 110207>$

[2] Pasternak, Anne: Creative Time - The book, Princeton Architectural Press, 2008, p 227. 


\title{
ABSTRACTS
}

\author{
ARNÓTH, Ádám: INTERNAL WEALTH \\ Citation: Metszet, Vol 11, No 5 (2020), pp 18-25, DOI: 10.33268/Met.2020.5.1 \\ SYNAGOGUE RESTORATION, BUDAPEST, HUNGARY | Restoration Architect: Tamás KőNIG DLA and Péter WAGNER DLA \\ Originally designed in the Moorish Revival \\ style by Otto Wagner in 1873, this synagogue \\ served as a place of worship for the more \\ conservative members of Budapest's Jewish \\ community. WWII damage left the building \\ to the original design, the Torah Ark and \\ unusual use of Moorish decorative elements \\ have helped demonstrate why this building \\ is one of Budapest's significant historic \\ monuments.
}

\section{LÉVAI, Tamás: TIME TRAVEL}

Citation: Metszet, Vol 11, No 5 (2020), pp 26-31, DOI: 10.33268/Met.2020.5.2

PJ VILLA, KOLOZSVÁR (CLUJ-NAPOCA), ROMANIA | Architect: Miklós PÉTERFFY

Originally designed in 1937, an amazingly

exciting period for architecture any where, this

family home has recently been modernized. with updated technology, use of space and materials. Division of spaces has been achieved by feats of geometry on a grand developing a perfectionist feeling drawing inspiration from the 1930s desire for luxury. A possible destination for architectural

\section{CSANÁDY, Pál: MILITARY LEGACY}

Citation: Metszet, Vol 11, No 5 (2020), pp 32-37, DOI: 10.33268/Met.2020.5.3

LMCC ARTS CENTER, GOVERNORS ISLAND, NEW YORK, USA | Restoration Architect: Jay L. BERMAN

A former military base has seen a nineteenth century munitions warehouse converted into a venue for the arts by the Lower Manhattan Cultural Council with the intention of creating spaces for temporary exhibitions, studio spaces and public events. As one of the few green park areas of New York this offers a location not only for the arts but also for leisure time activities. The key to this project's success being the fact that a minimum level of work was required due to the architectural strength of the existing building.

Citation: Metszet, Vol 11, No 5 (2020), pp 38-43, DOI: 10.33268/Met.2020.5.4

STADT CASINO, BASEL, SWITZERLAND | Architects: HERZOG and DE MEURON

The designers of this project have taken an approach similar to that of an Eszterházy novel: travelling through a multifaceted history of spaces from point of view to point of view. This might be an act of fantasy or irony resulting in a restoration of neobaroque elements, insertion of contemporary interventions, resulting in maintaining the original acoustic quality of the concert hall and improved non-performance circulation areas: foyer, stairwells and corridors which now create a new sequential flow throughout the building complex.

\section{WARE-NAGY, Orsolya: REALISTIC, WALK-IN MODEL, OR THE NEW OLD Citation: Metszet, Vol 11, No 5 (2020), pp 44-49, DOI: 10.33268/Met.2020.5.5 RESTORATION OF THE HORSE RIDING-HALL, BUDAPEST, HUNGARY | Restoration Architects: Ferenc POTZNER}

A key element of the National Hauszmann project to restore or rebuild monumental buildings in Budapest's Castle District includes this Riding-Hall damaged in WWII and finally demolished in the 1950s. Obviously when a building is totally demolished rebuilding to original plans will not occur due to changes in materials, construction methods or statutory requirements. The question arising being that of "is this a faithful reconstruction or a full-scale architectural model" erected in an attempt to satisfy grandiose plans or a false sense of history?

\section{CSONTOS, Györgyi - TÓTH, Timea: ENLIGHTENMENT}

Citation: Metszet, Vol 11, No 5 (2020), pp 50-57, DOI: 10.33268/Met.2020.5.6

CHURCH OF THE STIGMATIZATION OF SAINT FRANCIS, BUDAPEST, HUNGARY | Restoration Architects: Judit Z. HALMÁGYI and

\section{Tamás TÓTH}

Often religious buildings fall into a state of neglect, here a Roman Catholic Church suffered from a combination of problems: being part of a none too sympathetic urban composition and neglect due to dissolution during the communist era. The architects responsible for the restoration started by making a full digital survey of the building from which analysis of required works could be implemented. Improvements to the

\section{DOMBÓVÁRI, János: REPAIRED FINALE}

Citation: Metszet, Vol 11, No 5 (2020), pp 58-63, DOI: 10.33268/Met.2020.5.7

HARD ROCK HOTEL, BUDAPEST, HUNGARY Architects: László SZÁSZ and Erzsébet HAJNÁDY

Following the established business model of the Hard Rock company design concepts are handled by their local franchise partner. Here the decision was made to respect the existing building's elevations, whilst adding a three storey high golden crown that responds to the location, Nagymezó Utca's, Broadway like ambitions. To lift a corner site architecturally building's fabric, quality of lighting and its place in the urban context have been vastly improved upon. 